\title{
Conservation of Body Sections and Organs of the Narrownose Smooth-hound, Mustelus schmitti (Pisces, Chondrichthyes), by Silicone Injection at Room Temperature to be Used in Comparative Anatomy learning
}

\author{
Conservación de Secciones Corporales y Órganos de Gatuzo, Mustelus schmitti (Pisces, \\ Chondrichthyes), por Inyección de Silicona a Temperatura Ambiente para ser \\ Utilizados en el Aprendizaje de Anatomía Comparada
}

Albertina Inés Popp ${ }^{1,2}$; Ana Paula Basso ${ }^{1,2}$; Mariela Victoria Lodovichi ${ }^{1}$ \& Nora Silvia Sidorkewicj $^{1,2}$

POPP, A. I.; BASSO, A. P.; LODOVICHI, M. V. \& SIDORKEWICJ, N. S. Conservation of body sections and organs of the narrownose smooth-hound, Mustelus schmitti (Pisces, Chondrichthyes), by silicone injection at room temperature to be used in Comparative Anatomy learning. Int. J. Morphol., 36(2):413-418, 2018.

SUMMARY: Comparative Anatomy deals with the study of the ontogenetic and phylogenetic changes of the vertebrates, requiring complementing the theoretical aspects with the observation of structures in specimens belonging to different taxonomic groups. The aim of the present study was to test the injection of silicone at room temperature in organs and trunk sections of Mustelus schmitti as an alternative to the plastination technique. Samples consisted in brain, eyes, heart, proximal end of the ventral aorta, digestive tract, spleen, pancreas, kidneys, testis and cross body section at a pre-caudal level. Material was fixed with formalin (10-5\%), dehydrated with growing concentrations of isopropyl (30\%-50\%-70\%-90\%-100\%-100\%), impregnated with diluted commercial silicone and cured at room temperature. The whole process took 66 days. The brain was the unique organ that could not undergo the complete procedure because it did not resist the injection of silicone. The other pieces resulted in materials that characterised by being off-colour, dry, semi-flexible, lightweight, odourless, and non-toxic. They showed no signs of fungal colonization or bacterial degradation after two years of being obtained. Shrinkage was observed, which ranged among 2-25\% for total length, and from 5-26\% for maximum width (mean values: 14 and $15 \%$, respectively), being testicle the organ that suffered greater shrinkage in both dimensions. The degree of contraction in length and width for each of the samples was generally similar (difference $\leq 3 \%$ ), indicating that not striking deformation occurred. Deformation was observed only for the trunk section, eye, stomach, pancreas and valvular intestine. The technique did not affect the morphology of the structures, allowing the correct visualization of all the basic features required to recognise them. We conclude that this simple and economic method is an adequate alternative to be implemented for the conservation of small-size materials with educational purposes in Comparative Anatomy courses.

KEY WORDS: Conservation techniques; Acetic silicone; Education; Dissection; Comparative Anatomy.

\section{INTRODUCTION}

Although there are a large number of published books on anatomy, some of them with excellent illustrations, so far no good substitute has been found for the use of cadaveric specimens in the achievement of a real understanding of the human body (Fonseca-Matheus, 2012). The use of dead bodies that can be manipulated, have been demonstrated to be the most effective method in anatomical studies because the students develop skills and aptitudes in tissue manipulation while becoming aware of positions, textures and topographic relationships, leading ultimately to a meaningful learning (Bravo \& Inzunza, 1995; Inzunza \& Bravo, 1999; Older, 2004; Bravo, 2006; Fonseca-Matheus). The same goes in the field of animal anatomy, although a considerable debate exists around

\footnotetext{
${ }^{1}$ Departamento de Biología, Bioquímica y Farmacia, Universidad Nacional del Sur (UNS), San Juan 670, 8000 Bahía Blanca, Argentina.

${ }^{2}$ Instituto de Ciencias Biológicas y Biomédicas del Sur (INBIOSUR), Consejo Nacional de Investigaciones Científicas y Técnicas (CONICET-UNS)
} 
POPP, A. I.; BASSO, A. P.; LODOVICHI, M. V. \& SIDORKEWICJ, N. S. Conservation of body sections and organs of the narrownose smooth-hound, Mustelus schmitti (Pisces, Chondrichthyes), by silicone injection at room temperature to be used in Comparative Anatomy learning. Int. J. Morphol., 36(2):413-418, 2018.

animal dissection that is far from being resolved in educational contexts (Oakley, 2012). Such a debate is present within the course Comparative Anatomy, which composes the curriculum of the Bachelor's Degree in Biological Sciences of the Universidad Nacional del Sur (Bahía Blanca, Argentina).

Comparative Anatomy is a discipline that deals with the study of the changes occurring during embryonic development (ontogenetic change) and throughout the evolutionary history (phylogenetic change) of the different groups of vertebrates, mainly gnathostomes (fish, amphibians, reptiles, birds and mammals). The study of these aspects requires of the intensive use of images and conceptual models, which should be complemented by observation of structures in specimens belonging to the different taxonomic groups; this practice aids students to recognise the variation that exists in nature and to elucidate evolutionary patterns. However, as mentioned above, dissections are increasingly difficult to perform because of the many ethical issues surrounding this topic and the growing resistance of students to the animal sacrifice. On the other hand, although there are models and other types of elaborate didactic materials in the market, their acquisition represents an unfeasible option since they involve a very high economic cost and are insufficient to cover all the contents. In this context, techniques such as plastination appear as promising tools to obtain a great amount of perdurable material to be used during our classes.

Plastination is a revolutionary technique of preservation of tissues, organs and whole bodies created by Gunther von Hagens in 1977 (von Hagens et al., 1987). The principle behind it consists in the replacement of tissue water and lipids by curing polymers, which allow retaining structural details down to the histological level (von Hagens et al.). The advantages of this technique in the fields of research and teaching have been widely recognised (Prasad et al., 2015 and references therein); its main benefit is that it allows obtaining materials as real as those collected from recently dissected specimens, with the additional advantage of being dry, odourless and non-toxic, being therefore suitable to be stored for a long time and manipulated in the laboratory or in the class without any special protective equipment. Integrating plastinated specimens into a teaching environment has been shown to afford positive educational outcomes in the classroom (Latorre et al., 2007, 2016; Fruhstorfer et al., 2011; Riederer, 2014), providing the benefit of greater tactile interaction with the specimens which may result in an increased time spent with the material (Kumro et al., 2013).
Basically, plastination consists of three successive steps, previous fixation or not of the specimen: dehydration, forced impregnation and curing. Unfortunately, start-up costs to set up a plastination lab and to obtain plastinated specimens using traditional methods used to be prohibitive for institutions with limited resources, superimposing restrictions to its implementation. For this reason, although the essence of the technique has remained constant over the years, considerable research efforts have been made worldwide not only to improve results and reduce the risks generated during the process, but also to decrease costs through the use of cheaper drugs and alternatives that avoid the use of special equipment (e.g. Baptista et al., 1992; Zheng et al., 2000; Henry, 2007; Ameko et al., 2013; Kumro et al.; Manjunatha, 2013; Ottone et al., 2015; Ekim et al., 2017).

The aim of the present study was to test the injection at room temperature as an alternative step to the forced impregnation by a vacuum system traditionally used in plastination, in organs and trunk sections of the narrownose smooth-hound, Mustelus schmitti.

\section{MATERIAL AND METHOD}

An adult male narrownose smooth-hound, Mustelus schmitti (total length: $75.23 \mathrm{~cm}$ ) was obtained from a local fisherman. The fish was immediately dissected and the organs were placed in separated glass containers. The samples selected to be treated were brain, eyes, heart, proximal end of the ventral aorta (attached to the heart), kidneys, testis, and a block consisting of the distal part of the oesophagus, stomach, intestine, spleen and pancreas. A 2-cm-thick-section of the trunk at a pre-caudal level (between the caudal end of the claspers and the beginning of the anal fin) was also obtained.

The whole process of the technique implemented was conducted at room temperature and under the strict security protocols commonly used at the Universidad Nacional del Sur (use of protective gloves, lab coats, respirators and goggles; manipulation under fume hood). In every step, flotation of the material was prevented by using a stainless steel grate to allow full contact of the samples with solutions. Each piece was measured before and after the process (total length and maximum width) by means of a digital calliper $(0.01 \mathrm{~mm})$, and the rates of shrinkage $(\%)$ were calculated.

Fixation. The material was injected with $10 \%$ formalin using $21 \mathrm{G}$ needles, and immersed in the same solution for seven 
days. After that, it was changed to a $5 \%$ formalin solution for seven days, and this step was repeated once again.

Dehydration. Samples were submerged in growing concentrations of isopropyl alcohol $(30 \%-50 \%-70 \%-$ $90 \%-100 \%-100 \%)$. For each concentration, they were kept for a period of six days, changing the solution once (at the third day). The liquid was agitated once a day during the whole process.

Impregnation. After the final isopropyl alcohol bath, a solution was prepared by diluting acetic commercial silicone (mixture of polydimethylsiloxanes and alkyltriacetoxysilanes) with turpentine (1:7 dilution). Each piece was injected with this solution by using $21 \mathrm{G}$ needles and 1-5 ml syringes. Injection was performed until material began to leak out, forcing the silicone to impregnate it as much as possible without altering the original morphology of the organs. This procedure was repeated after two days.

Post-impregnation. The polymer mixture was wiped off, and the pieces were placed over capless glass containers for one week.

\section{RESULTS AND DISCUSSION}

The total process took 66 days (fixation: 21; dehydration: 36 ; impregnation: 2; post-impregnation: 7 days). The brain was the unique organ that could not undergo the complete procedure because it did not resist the injection of silicone. Maybe a longer fixation period with a higher concentration of formalin would have been necessary (Henry et al., 1997, see below), to counteract the friability of the organ.

The technique applied yielded pieces that were dry, semi-flexible, lightweight, odourless and non-toxic. They showed no signs of fungal colonization or bacterial degradation after two years of being obtained, resulting therefore also of great durability.

All treated samples were markedly discoloured with respect to the fresh material (Fig. 1). Different authors have recommended using lower formaldehyde concentrations and reducing the duration of the fixation period to the shortest possible in order to preserve the natural colour and to maintain a greater flexibility of the specimens (Bickley et al., 1987; Henry et al.). However, some organs such as brain has been cited as requiring to be fixed with a high concentration (10-20\%) of formaldehyde during
A
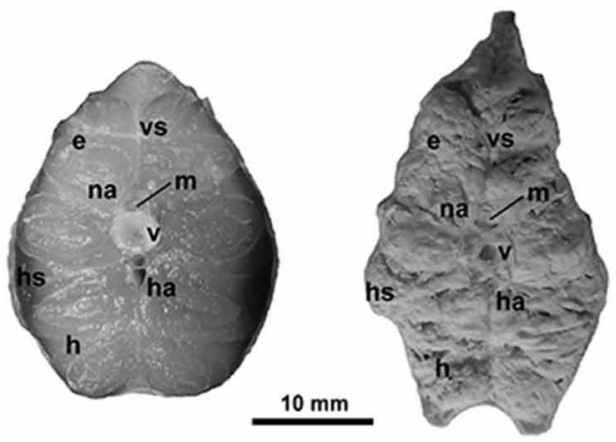

B
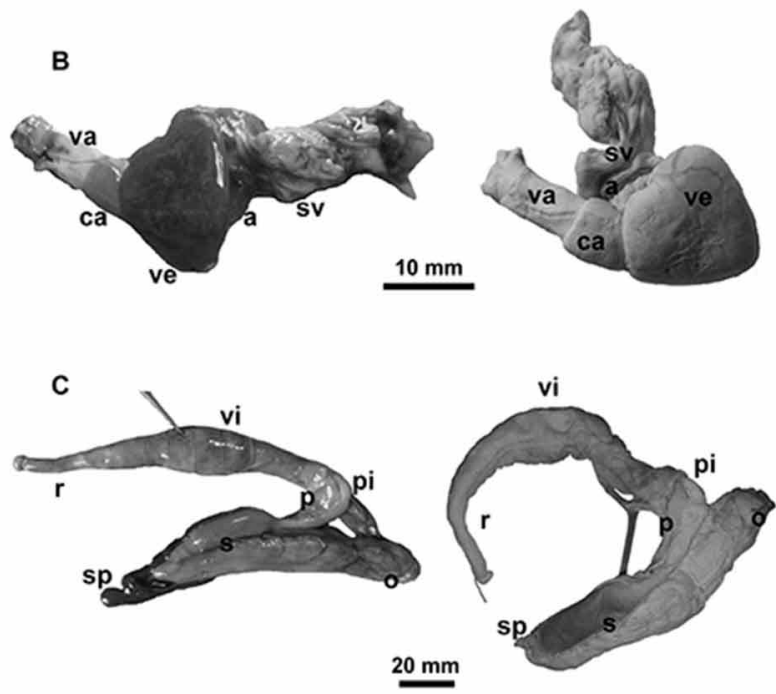

Fig. 1. Macroscopic views of some of the material of Mustelus schmitti, in their recently dissected state (left) and after the whole process (right). A: cross section of the trunk at a precaudal level; B: heart in ventral view; $\mathrm{C}$ : block constituted by part of the digestive tract, pancreas and spleen in ventral view. Abbreviations: a: atrium; ca: conus arteriosus; e: epaxial muscles; h: hipaxial muscles; ha: hemal arch; hs: horizontal septum; m: spinal medulla; na: neural arch; o: oesophagous; p: pancreas; pi: proximal intestine; r: rectum; s: stomach; sp: spleen; sv: sinus venosus; v: vertebral body; va: ventral aorta; ve: ventricle; vi: valvular intestine; vs: vertical septum.

several months to prevent shrinkage during impregnation (Henry et al.). We have tried a fixation with a relatively high formalin concentration (10-5-5\%) during a long period (total 21 days) because we did not know at first the answer of our material to the process. Other recommendations to minimise colour loss are freeze fixation, or fixation at $5{ }^{\circ} \mathrm{C}$ or lower (Bickley et al.; Oostrom, 1987). 
POPP, A. I.; BASSO, A. P.; LODOVICHI, M. V. \& SIDORKEWICJ, N. S. Conservation of body sections and organs of the narrownose smooth-hound, Mustelus schmitti (Pisces, Chondrichthyes), by silicone injection at room temperature to be used in Comparative Anatomy learning. Int. J. Morphol., 36(2):413-418, 2018.

Table I. Initial and final lengths (Li, Lf) and widths (Wi, Wf) of the organs and trunk section of Mustelus schmitti undergone processing of the technique applied.

\begin{tabular}{|c|c|c|c|c|}
\hline \multirow[t]{2}{*}{ Material } & \multicolumn{2}{|c|}{ Total length (mm) } & \multicolumn{2}{|c|}{ Maximum width (mm) } \\
\hline & $\mathrm{Li}$ & $\mathrm{Lf}$ & Wi & Wf \\
\hline Right eye* & 11.88 & 11.40 & 7.82 & 7.00 \\
\hline \multicolumn{5}{|l|}{ Heart: } \\
\hline sinus venosus & 9.80 & 7.95 & 7.23 & 5.99 \\
\hline atrium & 9.50 & 8.22 & 9.10 & 8.07 \\
\hline ventricle & 12.13 & 10.57 & 17.31 & 15.08 \\
\hline conus arteriosus & 5.01 & 4.59 & 4.97 & 4.56 \\
\hline Ventral aorta & 6.32 & 5.95 & 3.77 & 3.53 \\
\hline Stomach & 96.78 & 87.86 & 22.48 & 18.13 \\
\hline Proximal intestine & 37.46 & 34.64 & 4.35 & 4.14 \\
\hline Valvular intestine & 89.85 & 71.39 & 17.92 & 15.66 \\
\hline Rectum & 21.43 & 17.14 & 4.68 & 3.85 \\
\hline Spleen $* *$ & --- & --- & 19.84 & 16.43 \\
\hline Pancreas & 25.28 & 24.87 & 6.59 & 5.28 \\
\hline Deferent duct*** & 115.47 & 111.67 & --- & --- \\
\hline Right testis & 82.39 & 61.47 & 9.52 & 7.09 \\
\hline Right kidney & 59.26 & 51.01 & 8.49 & 7.46 \\
\hline Trunk section* & 27.32 & 32.56 & 21.58 & 20.07 \\
\hline
\end{tabular}

* Maximum height was measured instead the parameters width (eye) and length (trunk section).

**The spleen was refolded over itself during the process, so final length could not be measured.

*** $\mathrm{Li}$ and $\mathrm{Lf}$ were taken for the duct in its natural rolled up state. Width (Wi and Wf) was not measured owing to its minute magnitude.

All pieces diminished in length and width during the process, except the trunk section that increased its height in $19 \%$ (Table I), suffering a deformation. The latter may be related by the fact that the body section was subjected to the process without previous removal of the integument. Tiedemann (1987) stated that, when working with traditional silicones (Biodur S10/S3 mixture) and a vacuum system, specimens covered with skin, like fish, must be infiltrated with polymer prior to forced impregnation to avoid compression-induced shrinkages owing to different rates of exchange between solvents and silicone through skin. Although we did not use standard silicones or a vacuum system, and taking into account that the method applied was based on the direct injection of silicone inside the sample, we expected no deformation to occur. We do not discard some kind of effect of differential stress in the tissue owing to the shape and orientation of the muscular fibres.

Shrinkage of the organs varied among 2 and $25 \%$ for total length, and from 5 to $26 \%$ for maximum width, with mean values of 14 and $15 \%$, respectively. Rates of contraction greater than $10 \%$ were observed in 9 (length) and 12 (width) pieces (Fig. 2). Testicle was the organ that suffered greater shrinkage, both in length $(25 \%)$ and width (26\%). This marked shrinkage could be explained by the relatively high fat concentration that characterise the gonadal tissues of the adult elasmobranch fishes, mainly mobilised from liver for gametogenesis (García-Garrido et al., 1990).

Notwithstanding the level of shrinkage varied considerably among organs, the degree of contraction in length and width for each of them was generally similar (difference $\leq 3 \%$ ), indicating that not striking deformation occurred. The exceptions were the eye, stomach, pancreas and valvular intestine that did suffered deformations, with differences between retractions of length and width that ranged from 6 to $18 \%$ (Fig. 2). Surprisingly, the first three (eye, stomach, pancreas) suffered a shrinkage much higher in width than in length, although their tissue constitution is quite different. For the valvular intestine the opposite situation was observed, which could be explained by the restriction posed by the spiral valve generating transverse stresses on the intestinal wall, which avoid widening or thinning of the organ, but not its shortening.

Although the technique applied affected colour quality, size and flexibility of the samples, it had no severe effect on its morphology (Fig. 1). All structures retained the same anatomical details as newly dissected organs, allowing the correct visualization of all the basic features required to recognise them.

The simple method described in the present work is more cost-effective than the traditional process of 


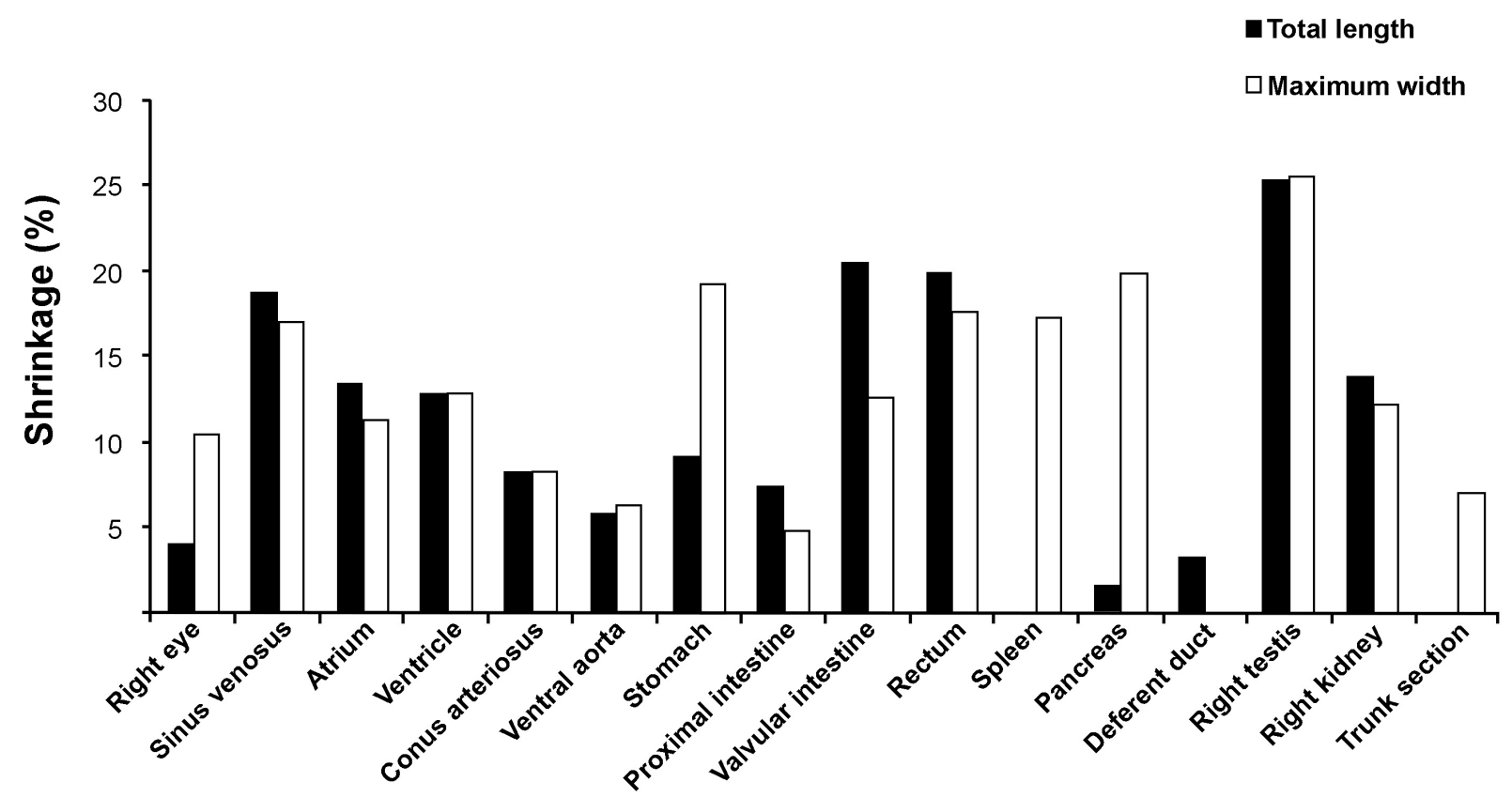

Fig. 2. Level of shrinkage observed in the organs and trunk section of Mustelus schmitti.

plastination, considering the high costs that represent the standard drugs and the special equipment involved in it. The level of the morphological details that are preserved in the samples, coupled with the ease of implementation and economic benefits, makes it an adequate alternative to be implemented for the conservation of small-size materials with educational purposes in Comparative Anatomy courses. We hope this contribution to be useful in searching other alternatives to plastination, which would allow getting a collection of lab material that can be utilised repeatedly with educational purposes without the problems of toxicity that means the conservation in formaldehyde, reducing the risks of exposition of the students and teaching staff to toxic drugs.

POPP, A. I.; BASSO, A. P.; LODOVICHI, M. V. \& SIDORKEWICJ, N. S. Conservación de secciones corporales y órganos de gatuzo, Mustelus schmitti (Pisces, Chondrichthyes), por inyección de silicona a temperatura ambiente para ser utilizados en el aprendizaje de Anatomía Comparada. Int. J. Morphol., 36(2):407-412, 2018.

RESUMEN: La Anatomía Comparada abarca el estudio de los cambios ontogenéticos y filogenéticos sufridos por los vertebrados, requiriendo complementar los aspectos teóricos con la observación de estructuras en especímenes pertenecientes a los distintos grupos taxonómicos. El objetivo del presente trabajo fue testear la inyección de silicona a temperatura ambiente en órganos y secciones corporales de Mustelus schmitti como alternativa a la técnica de plastinación. Las estructuras seleccionadas fueron en- céfalo, ojos, corazón, extremo proximal de aorta ventral, tracto digestivo, bazo, páncreas, riñón, testículo y sección transversal del cuerpo a nivel pre-caudal. El material se fijó con formaldehído (10-5\%), se deshidrató con concentraciones crecientes de alcohol isopropílico (30\%- $50 \%-70 \%-90 \%-100 \%-100 \%)$, se impregnó con silicona comercial diluida y se curó a temperatura ambiente. El proceso completo duró 66 días. El encéfalo fue el único órgano que no resistió el tratamiento debido a su friabilidad. Las demás piezas dieron como resultado materiales incoloros, secos, semi-flexibles, livianos, inodoros y no-tóxicos. No se evidenciaron síntomas de colonización fúngica ni bacteriana luego de dos años de obtenidos. Se observó contracción del material que osciló entre 2-25\% para la longitud total, y entre 5-26\% para el ancho máximo (promedios: 14 y $15 \%$, respectivamente), siendo el testículo el órgano que mayor disminución registró en ambas dimensiones. El grado de contracción en longitud y en ancho fue generalmente similar para cada una de las muestras (diferencia $\leq 3$ $\%$ ), indicando que no ocurrió una deformación notoria. Solo se observó deformación en la sección corporal, ojo, estómago, páncreas e intestino valvular. La técnica no afectó la morfología de las estructuras, permitiendo la correcta visualización de todas las características diagnósticas requeridas para su reconocimiento. Concluimos que este método simple y económico representa una alternativa adecuada para ser implementada en la conservación de materiales de pequeño tamaño con fines educativos en los cursos de Anatomía Comparada.

PAlABRAS ClAVE: Técnicas de Conservación; Silicona acética; Educación; Disección; Anatomía Comparada. 
POPP, A. I.; BASSO, A. P.; LODOVICHI, M. V. \& SIDORKEWICJ, N. S. Conservation of body sections and organs of the narrownose smooth-hound, Mustelus schmitti (Pisces, Chondrichthyes), by silicone injection at room temperature to be used in Comparative Anatomy learning. Int. J. Morphol., 36(2):413-418, 2018.

\section{REFERENCES}

Ameko, E.; Milla-Amekor, E.; Achio, S.; Alhassan, S. S. A. \& Ekpe, J. Suitability of a modified adapted standard (S10) method for plastinating three species of fishes (Tilapia, African Catfish and African Bonytongue). Int. J. Pure Appl. Sci. Technol., 16(2):63-74, 2013.

Baptista, C. A. C.; Bellm, P.; Plagge, M. S. \& Valigosky, M. The use of explosion proof freezers in plastination: are they really necessary? $J$. Int. Soc. Plastination, 6:34-7, 1992.

Bickley, H. C.; Conner, R. S.; Walker, A. N. \& Jackson, R. L. Preservation of tissue by silicone rubber impregnation. J. Int. Soc. Plastination, 1(1):30-9, 1987.

Bravo, H. \& Inzunza, H. O. Assessment of some software for anatomy and neuroanatomy teaching at Faculty of Medicine, Pontificia Universidad Católica de Chile. Rev. Chil. Anat., 13(1):79-86, 1995.

Bravo, H. Plastination an additional tool to teach anatomy. Int. J. Morphol., 24(3):475-80, 2006

Ekim, O.; Hazıroglu, R. M.; Insal, B.; Bakıcı, C.; Akgün, R. O. \& Tunali, S. A modified S10B silicone plastination method for preparation and preservation of scaled reptile specimens. Ank. Üniv. Vet. Fak. Derg., 64(3):155-60, 2017.

Fonseca-Matheus, J. Conservación de piezas anatómicas para la enseñanza en carreras médicas. Gac. Cienc. Vet. 17(1):5-10, 2012.

Fruhstorfer, B. H.; Palmer, J.; Brydges, S. \& Abrahams, P. H. The use of plastinated prosections for teaching anatomy--the view of medical students on the value of this learning resource. Clin. Anat., 24(2):24652, 2011.

García-Garrido, L.; Muñoz-Chapuli, R. \& de Andres, A. V. Serum cholesterol and triglyceride levels in Scyliorhinus canicula (L.) during sexual maturation. J. Fish Biol., 36(4):499-509, 1990.

Henry, R. W. Silicone plastination of biological tissue: Room-temperature technique-North Carolina technique and products. J. Int. Soc. Plastination, 22:26-30, 2007.

Henry, R. W.; Janick, L. \& Henry, C. Specimen preparation for silicone plastination. J. Int. Soc. Plastination, 12(1):13-7, 1997.

Inzunza, O. \& Bravo, H. Impact of two software of human anatomy in the performance of the students practical knowledge. Rev. Chil. Anat., 17(2):205-9, 1999.

Kumro, S. L.; Crocker, A. V. \& Powell, R. L. Injection plastination: A lowtech, inexpensive method for silicone preservation of small vertebrates. J. Plastination, 25(1):12-7, 2013.

Latorre, R. M.; García-Sanz, M. P.; Moreno, M.; Hernández, F.; Gil, F.; López, O.; Ayala, M. D.; Ramírez, G.; Vázquez, J. M.; Arencibia, A. \& Henry, R. W. How useful is plastination in learning anatomy? J. Vet. Med. Educ., 34(2):172-6, 2007.

Latorre, R.; Bainbridge, D.; Tavernor, A. \& López Albors, O. Plastination in anatomy learning: An experience at Cambridge University. J. Vet. Med. Educ., 43(3):226-34, 2016.

Manjunatha, K. Evaluation of Indigenous Plastination Technique -vsAvailable Plastination Techniques in the Preservation of Anatomical Specimens. PhD Thesis. Bidar, Karnataka Veterinary, Animal and Fisheries Sciences University, 2013.

Oakley, J. Science teachers and the dissection debate: Perspectives on animal dissection and alternatives. Int. J. Environ. Sci. Educ., 7(2):25367, 2012.

Older, J. Anatomy: a must for teaching the next generation. Surgeon, 2(2):7990, 2004.

Oostrom, K. Fixation of tissue for plastination: General principles. J. Int. Soc. Plastination, 1(1):3-11, 1987.

Ottone, N. E.; Cirigliano, V.; Bianchi, H. F.; Medan, C. D.; Algieri, R. D.; Borges Brum, G. \& Fuentes, R. New contributions to the development of a plastination technique at room temperature with silicone. Anat. Sci. Int., 90(2):126-35, 2015.

Prasad, G.; Karkera; B.; Pandit, S.; Desai, D. \& Tonse, R. G. Preservation of tissue by plastination: A review. Int. J. Adv. Health Sci., 1(11):27-31, 2015.

Riederer, B. M. Plastination and its importance in teaching anatomy. Critical points for long-term preservation of human tissue. J. Anat., 224(3):309$15,2014$.

Tiedemann, K. Tools for the infiltration of dehydrated specimens with silicone rubber. J. Int. Soc. Plastination, 1(2):25-8, 1987.

von Hagens, G.; Tiedemann, K. \& Kriz, W. The current potential of plastination. Anat. Embryol. (Berl.), 175(4):411-21, 1987.

Zheng, T. Z.; Xuegui, Y.; Ling, C. \& Jingren, L. The history of plastination in China. J. Int. Soc. Plastination, 15(1):25-9, 2000.

\section{Corresponding author \\ Dra. Nora S. Sidorkewicj \\ Prof. Adjunto Anatomía Comparada \\ Dpto. Biología, Bioquímica y Farmacia \\ Universidad Nacional del Sur \\ (8000) Bahía Blanca \\ ARGENTINA}

Email: nsidorke@criba.edu.ar

Received: 28-06-2017

Accepted: 20-10-2017 